\title{
Analisis Kemampuan Pemecahan Masalah Matematis Siswa dalam Menyelesaikan Soal Open-Ended pada Materi Lingkaran Ditinjau dari Minat Belajar
}

\author{
Yesi Sapitri ${ }^{1}$, Citra Utami ${ }^{2}$, Mariyam ${ }^{3}$ \\ STKIP Singkawang, Singkawang, Indonesia \\ yesisapitri111996@gmail.com ${ }^{1}$, citrautami1990@gmail.com ${ }^{2}$, mariyam.180488@gmail.com ${ }^{3}$
}

\section{Kata Kunci: \\ Kemampuan Pemecahan Masalah Matematis, Soal Open-Ended, Minat Belajar, Lingkaran}

\begin{abstract}
ABSTRAK
Tujuan penelitian ini adalah untuk mendeskripsikan kemampuan pemecahan masalah matematis siswa dalam menyelesaikan soal open-ended pada materi lingkaran ditinjau dari minat belajar. Metode penelitian ini merupakan penelitian deskriptif kualitatif. Subjek penelitian adalah siswa kelas VIIIE SMP Negeri 3 Singkawang. Teknik pengumpulan data dalam penelitian ini berdasarkan angket minat belajar, tes kemampuan pemecahan masalah matematis dan wawancara. Teknik analisis data yang digunakan adalah Model Miles dan Huberman, yaitu reduksi data, penyajian data, dan penarikan kesimpulan. Hasil penelitian menunjukkan bahwa, 1) kemampuan pemecahan masalah matematis siswa dalam menyelesaikan soal open-ended pada materi lingkaran ditinjau dari minat belajar tinggi mempunyai rata-rata sebesar 52,34 yang berada pada kategori sedang, 2) kemampuan pemecahan masalah matematis siswa dalam menyelesaikan soal open-ended pada materi lingkaran ditinjau dari minat belajar sedang mempunyai rata-rata sebesar 37,08 yang berada pada kategori sedang, dan 3) kemampuan pemecahan masalah matematis siswa dalam menyelesaikan soal open-ended pada materi lingkaran ditinjau dari minat belajar rendah mempunyai rata-rata sebesar 45,23 yang berada pada kategori sedang.
\end{abstract}

\section{PENDAHULUAN}

Matematika merupakan salah satu mata pelajaran yang dipelajari disetiap jenjang pendidikan, dari jenjang sekolah dasar hingga perguruan tinggi. Salah satu fungsi diberikannya mata pelajaran matematika adalah sebagai alat untuk memecahkan masalah baik dalam mata pelajaran lain, dalam dunia kerja, maupun dalam kehidupan sehari-hari. Hal ini dikarenakan menurut Tangio (2015:2) matematika merupakan ilmu yang mempelajari tentang perhitungan, pengkajian dan menggunakan nalar atau kemampuan berfikir seseorang secara logika dan pikiran yang jernih. Pemecahan masalah sangat penting dalam pembelajaran matematika, karena proses pemecahan masalah akan menjadikan pemahaman siswa lebih baik.

Kemampuan pemecahan masalah matematis merupakan kemampuan yang harus dimiliki siswa, karena pemecahan masalah memberikan manfaat yang besar kepada siswa dalam melihat relevansi antara matematika dengan mata pelajaran yang lain, serta dalam kehidupan nyata. Menurut Branca (Sumartini, 2016:12) kemampuan pemecahan masalah adalah kemampuan dasar dalam belajar matematika, sehingga kemampuan tersebut harusnya diberikan, dilatih, dan dibiasakan kepada peserta didik sedini mungkin. Hal ini sejalan dengan pendapat Suji (2017:63) yang mengatakan bahwa pemecahan masalah dalam pembelajaran matematika harus dikembangkan dalam proses pembelajaran 
siswa dan perlu dibiasakan untuk memecahkan masalah, baik masalah matematis maupun masalah kehidupan sehari-hari. Dengan demikian kemampuan pemecahan masalah merupakan kemampuan yang harus dimiliki oleh setiap siswa.

Dalam pembelajaran matematika, pada dasarnya siswa dituntut untuk berusaha sendiri mencari pemecahan masalah serta pengetahuan yang menyertainya untuk menghasilkan pengetahuan yang benar-benar bermakna. Siswa dapat dikatakan memiliki kemampuan pemecahan masalah jika siswa tersebut mampu memenuhi keempat indikator yang ada didalam pemecahan masalah yaitu kemampuan memahami masalah, kemampuan merencanakan masalah, kemampuan menyelesaikan masalah, serta kemampuan menafsirkan solusi. Oleh karena itu dengan belajar pemecahan masalah, peserta didik diharapkan dapat mengembangkan cara berpikir, kebiasaan, ketekunan dan rasa ingin tahu serta kepercayaan diri dalam situasi yang tidak biasa, yang akan melayani mereka dengan baik di luar kelas matematika.

Berdasarkan uraian di atas dapat disimpulkan bahwa pemecahan masalah merupakan hal penting dalam pembelajaran matematika disebabkan karena dalam kehidupan sehari-hari manusia memang tidak pernah dapat lepas dari masalah. Kemampuan pemecahan masalah juga merupakan suatu kemampuan yang harus dimiliki siswa dan harus dikembangkan untuk dapat menyelesaikan suatu permasalahan matematika karena dalam proses pemecahan masalah, siswa yang melakukan pemecahan masalah tersebut.

Di satu sisi kemampuan pemecahan masalah penting bagi siswa, tetapi kebanyakan siswa masih kesulitan dalam memecahkan masalah matematika. Sejalan dengan penelitian Purnamasari (2015) menyebutkan bahwa dalam menyelesaikan suatu soal open-ended siswa hanya mampu sampai tahapan memahami masalah, tetapi siswa meninggalkan tahapan-tahapan selanjutnya. Hal ini juga terlihat dari penelitian yang dilakukan oleh Darojat dan Kartono (2016:1) bahwa dalam menyelesaikan soal openended siswa yang memiliki kemampuan pemecahan masalah dalam kategori rendah hanya dapat menyelesaikan masalah sampai tahap memahami masalah, siswa yang memiliki kemampuan pemecahan masalah pada kualifikasi yang sedang dapat menyelesaikan masalah sampai tahap memeriksa kembali tetapi kurang teliti dalam melaksanakan rencana pemecahan dan untuk siswa yang berkemampuan tinggi dapat menyelesaikan masalah sampai tahap memeriksa kembali serta lebih teliti dalam melaksanakan rencana pemecahan masalah. Berdasarkan hal tersebut, terlihat bahwa kemampuan pemecahan masalah matematis dalam menyelesaikan soal open-ended siswa SMP masih rendah.

Lebih lanjut mengenai hasil dari penelitian Purnamasari (2015:3) diketahui bahwa rendahnya level kemampuan pemecahan masalah matematis siswa disebabkan oleh beberapa hal, seperti jarangnya penggunaan soal open-ended dalam pembelajaran matematika yang mana pada saat siswa diberikan latihan, soal yang digunakan lebih banyak bersifat rutin sehingga siswa kurang terampil dalam mengerjakan soal yang menurut siswa sulit. Kenyataan yang terjadi selama ini adalah pembelajaran matematika justru terbiasa menggunakan soal tertutup yang hanya berorientasi pada solusi tunggal. Siswa hanya sekedar diberikan soal sedemikian rupa dengan tipe soal tertutup dan dengan metode penyelesaian yang sangat umum. Kebiasaan menggunakan soal tertutup tanpa adanya pemberian soal open-ended akan menyebabkan siswa merasa aneh dan mengalami kesulitan ketika mereka menjumpai soal open-ended serta kurangnya kreatifitas siswa dalam menyelesaikan masalah matematika. Hal tersebut mengindikasi bahwa dalam pembelajaran matematika kemampuan siswa dalam menyelesaikan soal open-ended kurang diperhatikan sehingga mengakibatkan rendahnya kemampuan pemecahan masalah matematis siswa dalam menyelesaikan soal open-ended.

Selain itu ada fakta yang ditemukan peneliti di lapangan selama peneliti melaksanakan PPL di SMP Negeri 3 Singkawang yaitu bahwa siswa kurang dilatih untuk mengerjakan soal yang berbentuk openended (terbuka), siswa hanya terbiasa mengerjakan soal yang memiliki jawaban tunggal. Padahal dengan memberikan soal-soal open-ended guru dapat dengan mudah mengetahui apakah siswa 
tersebut sudah menguasai materi atau belum, karena setiap siswa nantinya akan memberikan jawaban yang berbeda-beda.

Fakta yang ada diperkuat dengan wawancara yang dilakukan peneliti kepada salah satu guru di SMP Negeri 3 Singkawang pada hari selasa tanggal 13 Februari 2018 yang mengungkapkan bahwa guru tersebut jarang sekali menggunakan soal open-ended dalam pembelajaran matematika, yang mana guru menyajikan masalah masih berpedoman pada buku. Hal tersebut dilakukan guru dikarenakan keterbatasan waktu dalam membuat soal dan juga masih rendahnya nilai matematika siswa pada materi lingkaran untuk soal yang biasa atau rutin.

Rendahnya kemampuan pemecahan masalah matematis selain disebabkan karena jarangnya penggunaan soal open-ended, juga dikarenakan minat belajar siswa yang rendah dalam pembelajaran. Menurut penelitian yang dilakukan oleh Ulvah dan Afriansyah (2016:142) faktor yang menyebabkan siswa mengalami kesulitan menyelesaikan soal dikarenakan adanya kondisi kelas yang pasif, dimana siswa kurang dilibatkan dalam pembelajaran. Samsiyah (2014:4) mengatakan pembelajaran matematika yang dilaksanakan guru, masih didominasi oleh aktivitas latihan-latihan untuk pencapaian mathematical basics skils semata, yang mana guru kurang memperhatikan pada aktivitas belajar siswa yang mengarah proses berpikir divergen karena guru tidak sempat mempertimbangkan untuk menganalisis kemampuan pemecahan masalah siswa, sehingga guru hanya memberikan soal-soal rutin pada saat pembelajaran maupun evaluasinya. Sehingga hal tersebut menjadi penyebab kurangnya minat siswa dalam belajar matematika.

Padahal di sisi lain minat sangat mempengaruhi siswa untuk belajar, sehingga secara tidak langsung berpengaruh terhadap kemampuan siswa. Sejalan dengan itu Holidun (2017:1) dalam penelitiannya menunjukkan bahwa siswa dengan kategori minat belajar tinggi mampu menyelesaikan soal dari tiaptiap tahapan pemecahan masalah dengan benar, siswa dengan kategori minat sedang dalam menyelesaikan soal memenuhi semua indikator namun beberapa tahapan lainnya masih kurang sistematis serta siswa dengan kategori minat rendah mampu menyelesaikan pada tahapan memahami masalah dan merencanakan masalah meskipun belum maksimal. Selain itu juga berdasarkan hasil penelitian Farahiya (2017:1) menyatakan siswa yang memiliki minat belajar tinggi dapat melaksanakan semua indikator pemecahan masalah walaupun belum sepenuhnya, siswa yang memiliki minat belajar sedang hanya mampu melaksanakan indikator pertama dan kedua, dan siswa yang memiliki minat belajar rendah belum mampu menguasai indikator kemampuan pemecahan masalah. Berdasarkan hasil penelitian tersebut, dapat ditarik kesimpulan bahwa minat belajar siswa masih kurang.

Lingkaran adalah materi dalam mata pelajaran SMP yang terdapat pada kelas VIII. Materi lingkaran juga merupakan salah satu materi yang dapat dikembangkan menjadi soal open-ended (Nurlita, 2015:38). Disamping itu, lingkaran merupakan materi dasar yang berkaitan dengan materi matematika lainnya yang akan dipelajari pada jenjang berikutnya. Materi lingkaran erat hubungannya dengan kehidupan sehari-hari, misalnya menghitung panjang busur sebuah roda dalam bentuk soal cerita. Namun, kebanyakan siswa masih mengalami kesulitan dalam memecahkan masalah pada soal openended khususnya pada materi lingkaran. Hal tersebut terjadi karena dalam memecahakan soal diperlukan kemampuan pemecahan masalah. Akan tetapi kemampuan pemecahan masalah siswa masih rendah.

Penggunaan soal open-ended pada pembelajaran matematika dan besarnya minat belajar merupakan hal yang harus diperhatikan oleh guru dalam mengajarkan matematika. Menurut Takahashi (Mahmudi, 2008:3) dengan menggunakan soal terbuka lebih memberi kesempatan kepada siswa untuk mengembangkan kompetensi mereka dalam menggunakan ekspresi matematik. Sumardyono (Sari, 2015:1) mengungkapkan bahwa untuk meningkatkan kemampuan siswa dalam hal pemecahan masalah, guru harus memberi soal yang tidak rutin agar siswa terpacu untuk mengembangkan kemampuan pemecahan masalah serta proses bernalar sesuai dengan tingkat pemahaman yang dimilikinya. Berkaitan dengan minat belajar, guru harus berusaha membangkitkan minat belajar siswa 
untuk menguasai pengetahuan yang terkandung dalam bidang studinya dengan cara yang kurang lebih sama dengan kiat membangun sikap positif. Apabila seorang siswa sudah memiliki minat belajar yang tinggi, maka sikap positif, menyukai dan aktif dalam belajar matematika akan mudah untuk dibangun.

Pada saat siswa mengalami kesulitan menyelesaikan soal, semestinya guru mengetahui penyebab dari kesulitan tersebut sehingga guru dapat mencari solusi untuk mengatasinya. Kesulitan tersebut bisa saja disebabkan oleh kurangnya kemampuan pemecahan masalah matematis dan rendahnya minat belajar siswa dalam pembelajaran. Oleh karena itu, salah satu cara mengetahui penyebab kesulitan tersebut, perlunya alat ukur untuk mengukur kemampuan pemecahan masalah matematis siswa dan kaitannya dengan minat belajar siswa.

Gambaran permasalahan di atas menunjukkan bahwa kemampuan pemecahan masalah matematis siswa dalam menyelesaikan soal open-ended masih tergolong rendah. Kenyataan tersebut mengisyaratkan bahwa kemampuan pemecahan masalah perlu mendapat perhatian yang lebih. Selain itu, minat belajar minat juga perlu diperhatikan karena minat belajar merupakan salah satu faktor yang dapat mempengaruhi tinggi rendahnya kemampuan pemecahan masalah dalam menyelesaikan soal open-ended. Berdasarkan uraian di atas peneliti ingin mengkaji lebih dalam tentang kemampuan pemecahan masalah matematis siswa dalam menyelesaikan soal open-ended pada materi lingkaran ditinjau dari minat belajar. Oleh karena itu, judul penelitian yang dipilih adalah "Analisis Kemampuan

Pemecahan Masalah Matematis Siswa Dalam Menyelesaikan Soal Open-Ended Pada Materi Lingkaran Ditinjau Dari Minat Belajar”.

\section{METODE PENELITIAN}

Jenis penelitian ini adalah jenis penelitian kualitatif dengan metode deskriptif. Adapun sekolah yang menjadi tempat penelitian adalah SMP Negeri 3 Singkawang kelas VIII yang beralamat di Jalan H.U. Bawadi No. 48 Singkawang Tengah Kota Singkawang. Subjek dalam penelitian ini adalah seluruh kelas VIIIE SMP Negeri 3 Singkawang yang berjumlah 30 siswa. Teknik pengambilan sampel pada penelitian ini dengan menggunakan teknik purposive sampling.

Teknik analisis data yang digunakan dalam penelitian ini adalah teknik analisis interaktif yang dikembangkan oleh Miles dan Huberman (Sugiyono, 2017:133) yaitu reduksi data (data reduction), penyajian data (data display) dan penarikan kesimpulan (verification). Dalam penelitian ini akan diperoleh data secara kuantitatif sehingga untuk menganalisis data didapatkan dari pemberian tes kemampuan pemecahan masalah, angket minat belajar dan wawancara kepada 9 siswa sebagai subjek wawancara terkait hasil tes yang dikerjakannya.

\section{HASIL DAN PEMBAHASAN}

Bagian ini berisi pembahasan hasil penelitian berupa deskripsi kemampuan pemecahan masalah matematis siswa (tinggi, sedang, rendah) dalam menyelesaikan soal open-ended ditinjau dari minat belajar (tinggi, sedang dan rendah) yang berpandu pada indikator kemampuan pemecahan masalah. Pada tiap soal memuat indikator kemampuan pemecahan masalah matematis dengan tipe soal openended yang berbeda-beda, yaitu soal nomor satu merupakan tipe soal open-ended yang terbuka hasil akhirnya, soal nomor dua merupakan tipe soal open-ended yang terbuka proses penyelesaiannya, dan soal nomor tiga merupakan tipe soal open-ended yang terbuka pengembangan lanjutannya.

\section{Kemampuan Pemecahan Masalah Matematis Siswa Dalam Menyelesaikan Soal Open-Ended Ditinjau Dari Minat Belajar Tinggi}

Hasil pengumpulan data selama penelitian diperoleh 8 siswa yang memiliki minat belajar tinggi dengan rata-rata nilai tes kemampuan pemecahan masalah matematis sebesar 52,34. Banyaknya siswa pada tiap-tiap kategori kemampuan pemecahan masalah matematis ditinjau dari minat belajar tinggi dapat dilihat pada Gambar 1. 


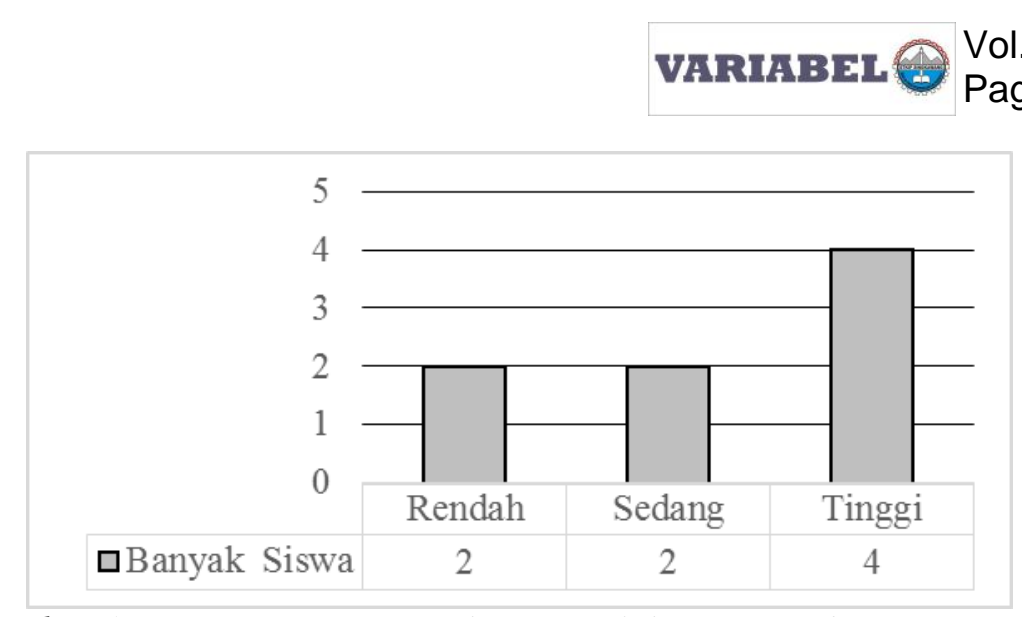

Gambar 1. Kemampuan Pemecahan Masalah Siswa Pada Tiap Kategori
Ditinjau Dari Minat Belajar Tinggi

Dari Gambar 1 terlihat bahwa kemampuan pemecahan masalah matematis siswa paling banyak berada pada kategori tinggi dan paling sedikit berada pada kategori rendah dan sedang yang mana mempunyai jumlah siswa yang sama. Hal ini berarti bahwa rata-rata kemampuan pemecahan masalah matematis siswa ditinjau dari minat belajar tinggi siswa kelas VIII SMP Negeri 3 Singkawang berada pada kategori sedang.

Berdasarkan hasil tes dan wawancara, kemampuan pemecahan masalah matematis siswa dengan minat belajar tinggi sudah cukup baik. Pada indikator pertama, hasil tes menunjukan bahwa siswa dapat menyelesaikan soal open-ended dengan baik yang mana siswa menuliskan apa yang diketahui dan yang ditanyakan secara benar dan hasil wawancara juga menunjukkan bahwa siswa dapat menjawab pertanyaan dengan baik yang mana siswa dapat menyebutkan apa yang diketahui dan yang ditanyakan secara benar. Pada indikator kedua, hasil tes menunjukan bahwa siswa dapat menyelesaikan soal openended dengan cukup baik yang mana sebagian siswa menuliskan rumus secara benar dengan satu cara saja dan hasil wawancara juga menunjukkan bahwa siswa dapat menjawab pertanyaan dengan cukup baik yang mana siswa dapat menyebutkan rumus yang digunakan untuk menyelesaikan soal tetapi hanya menyebutkan satu rumus saja. Pada indikator ketiga, hasil tes menunjukan bahwa siswa dapat menyelesaikan soal open-ended dengan cukup baik yang mana siswa menuliskan perhitungan secara benar pada satu rumus saja dikarenakan pada tahap merencanakan pemecahan masalah, siswa hanya merencanakan satu cara rumus saja dan hasil wawancara juga menunjukkan bahwa siswa dapat menjawab pertanyaan dengan cukup baik yang mana siswa dapat menyebutkan langkah-langkah perhitungan secara benar pada satu rumus saja. Pada indikator keempat, Hasil tes menunjukan bahwa siswa tidak dapat menyelesaikan soal open-ended dengan baik yang mana siswa tidak menuliskan pembuktian atas jawaban dari soal yang diselesaikannya dan hasil wawancara juga menunjukkan bahwa siswa tidak dapat menjawab pertanyaan sama sekali mengenai pembuktian hasil jawaban yang diperoleh.

Hasil di atas menunjukan bahwa siswa dengan minat belajar sedang mempunyai kemampuan pemecahan masalah yang sedang. Hal ini sejalan dengan penelitian Farahiya (2017:1) yang menyatakan bahwa siswa yang memiliki minat belajar tinggi dapat melaksanakan semua indikator pemecahan masalah walaupun belum bisa sepenuhnya.

\section{Kemampuan Pemecahan Masalah Matematis Siswa Dalam Menyelesaikan Soal Open-Ended Ditinjau Dari Minat Belajar Sedang}

Hasil pengumpulan data selama penelitian diperoleh 15 siswa yang memiliki minat belajar sedang dengan rata-rata nilai tes kemampuan pemecahan masalah matematis sebesar 37,08. Banyaknya siswa pada tiap-tiap kategori kemampuan pemecahan masalah matematis ditinjau dari minat belajar sedang dapat dilihat pada Gambar 2. 


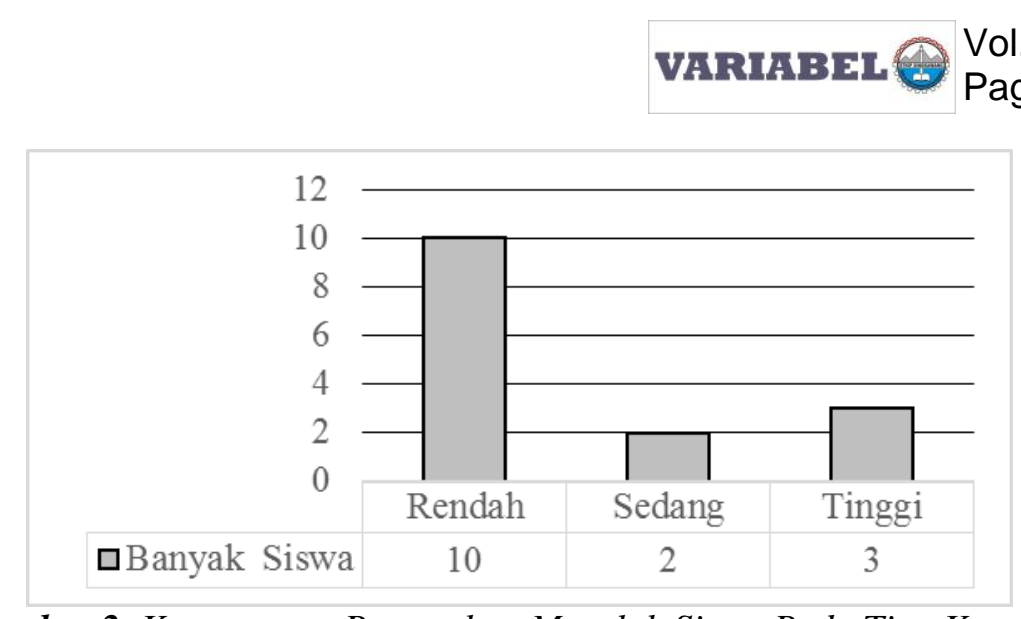

Gambar 2. Kemampuan Pemecahan Masalah Siswa Pada Tiap Kategori

Ditinjau Dari Minat Belajar Sedang

Dari Gambar 2 terlihat bahwa kemampuan pemecahan masalah matematis siswa paling banyak berada pada kategori sedang dan paling sedikit berada pada kategori tinggi. Hal ini berarti bahwa rata-rata kemampuan pemecahan masalah matematis siswa ditinjau dari minat belajar tinggi siswa kelas VIII SMP Negeri 3 Singkawang berada pada kategori sedang.

Berdasarkan hasil tes dan wawancara, kemampuan pemecahan masalah matematis siswa dengan minat belajar tinggi sudah cukup baik. Pada indikator pertama, hasil tes menunjukan bahwa siswa dapat menyelesaikan soal open-ended dengan baik yang mana siswa menuliskan apa yang diketahui dan yang ditanyakan secara benar dan hasil wawancara juga menunjukkan bahwa siswa dapat menjawab pertanyaan dengan baik secara benar. Pada indikator kedua, hasil tes menunjukan bahwa siswa dapat menyelesaikan soal open-ended dengan cukup baik yang mana siswa menuliskan rumus secara benar dengan satu cara saja dan hasil wawancara juga menunjukkan bahwa siswa dapat menjawab pertanyaan dengan cukup baik yang mana siswa dapat menyebutkan rumus yang digunakan untuk menyelesaikan soal tetapi hanya menyebutkan satu rumus saja. Pada indikator ketiga, hasil tes menunjukan bahwa siswa dapat menyelesaikan soal open-ended dengan cukup baik yang mana siswa menuliskan perhitungan secara benar pada satu rumus saja dikarenakan pada tahap merencanakan pemecahan masalah, siswa hanya merencanakan satu cara rumus saja dan hasil wawancara juga menunjukkan bahwa siswa dapat menjawab pertanyaan dengan cukup baik yang mana siswa dapat menyebutkan langkah-langkah perhitungan secara benar pada satu rumus saja. Pada indikator keempat, hasil tes menunjukan bahwa siswa tidak dapat menyelesaikan soal open-ended dengan baik yang mana siswa tidak menuliskan pembuktian atas jawaban dari soal yang diselesaikannya dan hasil wawancara juga menunjukkan bahwa siswa tidak dapat menjawab pertanyaan sama sekali mengenai pembuktian hasil jawaban yang diperoleh.

Hasil di atas menunjukan bahwa siswa dengan minat belajar sedang mempunyai kemampuan pemecahan masalah yang sedang. Hal ini sejalan dengan penelitian Holidun (2017) yang menunjukan bahwa siswa dengan minat belajar sedang dalam menyelesaikan soal pemecahan masalah memenuhi semua indikator kemampuan pemecahan masalah namun beberapa tahapan lainnya masih kurang sistematis.

\section{Kemampuan Pemecahan Masalah Matematis Siswa Dalam Menyelesaikan Soal Open-Ended Ditinjau Dari Minat Belajar Rendah}

Hasil pengumpulan data selama penelitian diperoleh 7 siswa yang memiliki minat belajar rendah dengan rata-rata nilai tes kemampuan pemecahan masalah matematis sebesar 45,23. Banyaknya siswa pada tiap-tiap kategori kemampuan pemecahan masalah matematis ditinjau dari minat belajar rendah dapat dilihat pada Gambar 3. 


\section{VARIABEI Vol. 2 No. 1 (2019)}

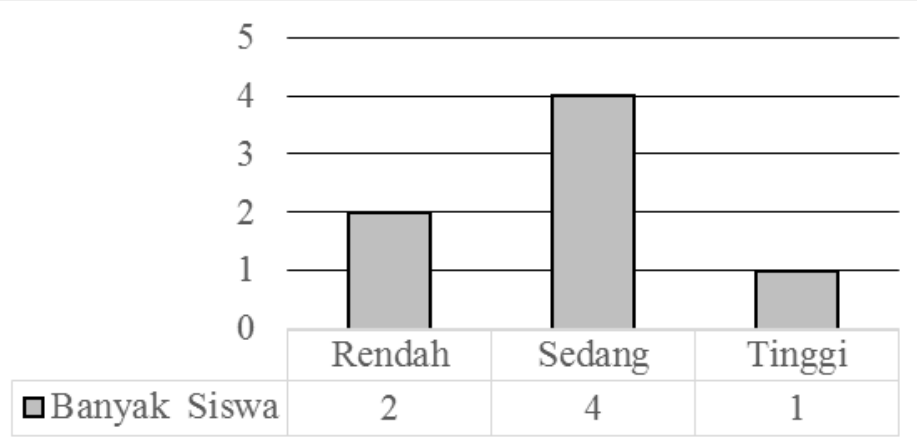

Gambar 3. Kemampuan Pemecahan Masalah Siswa Pada Tiap Kategori Ditinjau Dari Minat Belajar Rendah

Dari Gambar 3 terlihat bahwa kemampuan pemecahan masalah matematis siswa paling banyak berada pada kategori sedang dan paling sedikit berada pada kategori tinggi. Hal ini berarti bahwa rata-rata kemampuan pemecahan masalah matematis siswa ditinjau dari minat belajar tinggi siswa kelas VIII SMP Negeri 3 Singkawang berada pada kategori sedang.

Berdasarkan hasil tes dan wawancara, kemampuan pemecahan masalah matematis siswa dengan minat belajar tinggi sudah cukup baik. Pada indikator pertama, hasil tes menunjukan bahwa siswa dapat menyelesaikan soal open-ended dengan baik yang mana siswa menuliskan apa yang diketahui dan yang ditanyakan secara benar dan hasil wawancara juga menunjukkan bahwa siswa dapat menjawab pertanyaan dengan baik yang mana siswa dapat menyebutkan apa yang diketahui dan yang ditanyakan secara benar. Pada indikator kedua, hasil tes menunjukan bahwa siswa dapat menyelesaikan soal openended dengan cukup baik yang mana siswa menuliskan rumus secara benar dengan satu cara saja dan hasil wawancara juga menunjukkan bahwa siswa dapat menjawab pertanyaan dengan cukup baik yang mana siswa dapat menyebutkan rumus yang digunakan untuk menyelesaikan soal tetapi hanya menyebutkan satu rumus saja. Pada indikator ketiga, hasil tes menunjukan bahwa siswa dapat menyelesaikan soal open-ended dengan cukup baik yang mana siswa menuliskan perhitungan secara benar pada satu rumus saja dikarenakan pada tahap merencanakan pemecahan masalah, siswa hanya merencanakan satu cara rumus saja dan hasil wawancara juga menunjukkan bahwa siswa dapat menjawab pertanyaan dengan cukup baik yang mana siswa dapat menyebutkan langkah-langkah perhitungan secara benar pada satu rumus saja. Pada indikator keempat, Hasil tes menunjukan bahwa siswa tidak dapat menyelesaikan soal open-ended dengan baik yang mana siswa tidak menuliskan pembuktian atas jawaban dari soal yang diselesaikannya. Hasil wawancara juga menunjukkan bahwa siswa tidak dapat menjawab pertanyaan sama sekali mengenai pembuktian hasil jawaban yang diperoleh.

Hasil di atas menunjukan bahwa siswa dengan minat belajar sedang mempunyai kemampuan pemecahan masalah yang sedang. Hal ini sejalan dengan penelitian Darojat dan Kartono (2017) yang menunjukan bahwa siswa dengan kategori minat rendah mampu menyelesaikan pada tahapan memahami masalah dan merencanakan masalah meskipun tahapan lainnya belum maksimal.

\section{KESIMPULAN}

Berdasarkan data hasil penelitian dan pembahasan secara umum dapat disimpulkan bahwa 1) kemampuan pemecahan masalah matematis siswa dalam menyelesaikan soal open-ended pada materi lingkaran ditinjau dari minat belajar tinggi mempunyai rata-rata sebesar 52,34 yang berada pada kategori sedang, 2) kemampuan pemecahan masalah matematis siswa dalam menyelesaikan soal openended pada materi lingkaran ditinjau dari minat belajar sedang mempunyai rata-rata sebesar 37,08 yang berada pada kategori sedang, dan 3) kemampuan pemecahan masalah matematis siswa dalam menyelesaikan soal open-ended pada materi lingkaran ditinjau dari minat belajar rendah mempunyai rata-rata sebesar 45,23 yang berada pada kategori sedang. 


\section{DAFTAR PUSTAKA}

Darojat, L. dan Kartono (2016). Kemampuan Pemecahan Masalah Siswa Dalam Menyelesaikan Soal Open Ended Berdasarkan AQ Dengan Learning Cycle 7E. Unnes Journal of Mathematics Education Research, 5(1): 1-8.

Farahiya, A. (2017). Deskripsi Kemampuan Pemecahan Masalah Matematis Ditinjau Dari Minat Belajar Siswa SMP Negeri 1 Sumbang Pada Materi Faktorisasi Suku Aljabar. Skripsi. Universitas Muhammadiyah Purwekerto. Tidak Dipublikasikan.

Holidun (2017). Analisis Kemampuan Pemecahan Masalah Matematis Peserta Didik Kelompok Matematika Ilmu Alam (MIA) dan Ilmu-Ilmu Sosial (IIS) Kelas XI MAN 1 Bandar Lampung Ditinjau Dari Minat Belajar Matematika. Skripsi. Fakultas Tarbiyah dan Keguruan, Universitas Islam Negeri Raden Intan Lampung. Tidak Dipublikasikan.

Mahmudi, A. (2008). Mengembangkan Soal Terbuka (Open-Ended Problem) dalam Pembelajaran Matematika. Makalah Seminar Nasional Matematika, 1(1): 1-11.

Nurlita, M. (2015). Pengembangan Soal Terbuka (Open-Ended Problem) Pada Mata Pelajaran Matematika SMP Kelas VIII. Jurnal Pendidikan Matematika, 10(1): 38-49.

Purnamasari, P. D. (2015). Analisis Kemampuan Pemecahan Masalah Matematika Siswa Kelas XI SMK Muhammadiyah I Patuk Pada Pokok Bahasan Peluang. Jurnal Pendidikan Matematika dan Sains, 1(1): 1-7.

Samsiyah, N. (2014). Kemampuan Berpikir Kreatif Dalam Memecahkan Masalah Matematika OpenEnded Ditinjau Dari Tingkat Kemampuan Matematika Siswa Sekolah Dasar. Jurnal Pendidikan Matematika. 1(1): 1-8.

Sari, Y. M. (2015). Profil Kemampuan Siswa SMP Dalam Memecahkan Masalah Matematika OpenEnded Materi Pecahan Berdasarkan Tingkat Kemampuan Matematika. Jurnal Pendidikan Matematika, 1(1): 1-8.

Sugiyono. (2017). Metode Penelitian Kualitatif: untuk penelitian yang bersifat eksploratif, enterpretif, interaktif, dan konstruktif. Yogyakarta: Alfabeta.

Suji (2017). Penerapan Model Pembelajaran Kooperatif Tipe Teams Games Tournament Untuk Meningkatkan Kemampuan Pemecahan Masalah Matematis Siswa Pada Materi Segitiga. Jurnal Pendidikan Matematika Indonesia, 2(2): 1-9.

Sumartini, T. S. (2016). Peningkatan Kemampuan Pemecahan Masalah Matematis Siswa melalui Pembelajaran Berbasis Masalah. Jurnal Pendidikan Matematika, 8(3): 11-21.

Tangio, N. F. (2015). Deskripsi Kemampuan Pemecahan Masalah Matematika Pada Materi Soal Cerita Penjumlahan Dan Pengurangan Bilangan Bulat Dikelas VII SMP Negeri 1 Tapa. Jurnal Pendidikan Matematika, 1(1): 1-14.

Ulvah, S. dan Afriansyah (2016). Kemampuan Pemecahan Masalah Matematis Siswa Ditinjau Melalui Model Pembelajaran SAVI dan Konvensiona. Jurnal Riset Pendidikan, 2(2): 142-153. 